\title{
DESIGN AND EVALUATION OF SMART VENTILATION SYSTEM FOR MANAGING THE BIOENVIRONMENT OF THE HYDRPONICS SYSTEMS
}

\author{
Khaled k. Hegab* \\ ABSTRACT
}

From the technical, environmental and economic perspectives, using air conditioning systems (ACS) to manage the bioenvironmental conditions inside the sprouting chambers is considered a common mistake. Therefore, the main objective of this research is to design and evaluate a smart evaporative cooling system for executing efficient ventilation and conserving a suitable bioenvironment. Multi-stage smart evaporative cooling system (MSECS) was designed and installed to manage bioenvironment conditions inside the chamber. This system consists of Multi-stage evaporative cooling unit, smart control unit and air exhaust unit. To evaluate the proposed ventilation system two types of trials were executed. The first deals with temperature uniformity through the chamber and the second deals with production quantity and quality. Dry bulb temperature $T_{d b}$ was measured, analyzed and drawn to study the temperature uniformity. Three levels of relative humidity ratios $\mathrm{RH} \%$ and three types of multi-stage smart evaporative cooling systems were studied through complete randomize trial. Physical and chemical properties of the green fodder production were laboratory measured and statistically analyzed. The trials results statistical and graphical analysis revealed that: (1) Using MSECS with four exhaust fans led to significant decrease at ( $p<0.05)$ in the $T_{d b}$ variance comparing with the ACS. (2) Using MSECS with one or two exhaust fans hasn't significant effect at $(p<0.05)$ on the $T_{d b}$ variance comparing with the ACS. (3) Using MSECS with four exhaust fans led to in-crowd and uniformity of $T_{d b}$ contouring lines comparing with the ACS. (4) Using MSECS with four exhaust fans led to significant increase at $(p<0.05)$ in the desired properties of the green fodder such as percentage of dry matter Dm and crude protein Cp, and the in desired properties such as percentage of crude fiber $C_{f}$ and Ash.

\footnotetext{
*Agric. Eng. Dept., Faculty of Agric., Cairo University, Egypt.
} 
Therefore, the research conclusion is substitution of the ACS by smart MSECS with four exhaust fans for managing the bioenvironmental conditions of sprouting chambers at $T_{d b} 20^{\circ} \mathrm{C}$ and $\mathrm{RH} 75 \%$.

Keywords: Evaporative cooling - air conditioning - smart control-hydroponics system - ventilation system - design and evaluation - green fodder.

\section{1- INTRODUCTION}

1-1-Research Objective and Problem: Using air condoning units (ACU) for fixing air temperature and relative humidity $(\mathrm{RH})$ in sprouting chambers are considered a common technique. Since, the idea of ACU operation depends on the closed air circulation inside the chamber without refreshment. Sprouting process needs to air refreshment for executing physiological processes such as photosynthesis and disposing of pathogens such as fungi. Therefore, using air conditioning units (ACU) is considered partial solution of the problem. Oppositely, using evaporative cooling unit fixes air temperature and relative humidity (RH) and refreshes air, Amer et al. 2014. To keep heat balance for specific space, the calculated fixed cost of the evaporative cooling system installation is about half that of air conditioning system. The running cost for using evaporative cooling system is $1 / 8$ that of air conditioning system. Power consumption in evaporative cooling system is limited to the fan and water pump. This is due to the water vapor in evaporative cooling system is not recycled. Irreversibly, air conditioning system needs compressor that consumes most of the power in closed-cycle refrigeration. Also, special refrigerants, such as ammonia or CFCs, are used that could be toxic, expensive to replace, and contribute to ozone depletion, Chijioke 2017. As a result, the main objective of this research is to design and evaluate a smart evaporative cooling system for executing efficient ventilation and conserving a suitable bioenvironment inside the sprouting chambers.

1-2- Ventilation and Plant Growth: Environmental control of the plant growth room conditions is necessary to cultivate of off-season crops, extend the growing season, increase the potential yield, conserve water, control conditions for plant growth, and avoid pests and diseases. Ventilation systems are considered proper technique in control of temperature, relative humidity and $\mathrm{CO}_{2}$ rate inside greenhouses, Mashonjowa et al. 2010, Perone et al. 2017, Yasutake et al. 2017. 
1-3- Ventilation Techniques: Ventilation could be broken down into natural and mechanical ventilation. Mechanical ventilation such as evaporative cooling methods include fan pad, fogging system and roof evaporative cooling. Air water fogging system reduces air temperature $5^{\circ} \mathrm{C}$ compared to the control, Ganguly and Ghosh 2011. Using evaporative cooling system in greenhouses decreases indoor air temperature $13^{\circ} \mathrm{C}$ in comparing with outdoor air temperature, $\mathbf{O z}$ et al. 2009, Helmy et al. 2013, Ali and Hüseyin 2015. Changing greenhouse roof from single roof to double roof with shading of 50\% decreased 6.5$9.7{ }^{\circ} \mathrm{C}$ in the internal environment of the greenhouse, Mohammad et al. 2014. Fan pad evaporative cooling could be broken down into single and multistage. Two-stage evaporative cooling system is better than singlestage systems in thermal efficiency and energy saving, Hui and Cheung 2009, Rafique et al. 2018. Evaporative cooling system could be combined with wind catchers technology to the maximize value of cooling load, Noroozi and Veneris 2018. Evaporative cooling is ecofriendly and energy efficient technology. Therefore, it has been regularly used on large scale for domestic purpose as well as large industrial applications, Mehra et al. 2016. The main advantage of evaporative cooling system lies in its simplicity of operation and control and also in that it does not entail any risk of wetting the foliage. The main problem is large temperature and humidity gradients along the horizontal line, Sapounas et al. 2008. Dramatic temperature drop in a short term constitute a serious problem for evaporative cooling systems applications. Therefore, multistage regulation method must be used for controlling on evaporative cooling system, Han et al. 2018.

1-4- Technical Points in Ventilation: Location and design of the ventilation entrances and exits are considered one of main factors for maintaining homogeneous weather conditions inside the agricultural buildings, Villagrán et al. 2012. For a naturally ventilated greenhouse it is concluded that the total area of vent openings should be 15-30\% of floor area, Ganguly and Ghosh 2011. While as, this area depends on energy balance, humidity balance, and $\mathrm{CO}_{2}$ balance in the mechanical ventilation. Location of the fan-pad cooling system has particular influence on cooling effect, Chen et al. 2014. Increasing air temperature greater than $20{ }^{\circ} \mathrm{C}$ has a negative effects on greenhouses 
production in in tropical and subtropical countries, if some design criteria in the evaporative cooling system are not revised, Barreto-Mendes et al. (2017). Airflow rate through cellulose pad with thicknesses of $6-8$ inches is $250-350\left(\mathrm{CFM} / \mathrm{ft}^{2}\right)$. Min. reservoir capacity per unit pad area is $0.8-1.0$ $\left(\mathrm{Gal} / \mathrm{ft}^{2}\right)$ for cellulose pad with thicknesses of 6-8 inches, Worley, J. 2009. In comparing with cellulose pads, plastic grid block gives pressure drop is $11.05 \mathrm{~Pa}$ irrespective of the water flow, mean saturation efficiency is $82.50 \%$ and specific water consumption is $3.05 \mathrm{~L} \cdot \mathrm{h}-1 \cdot \mathrm{m}-2 \cdot{ }^{\circ} \mathrm{C}-1$, at an air velocity of $2 \mathrm{~m} \mathrm{~s}^{-1}$, Franco et al. 2014. Briefly, the plastic packing in the applied cooling system gives a pressure drop of $11.05 \mathrm{~Pa}$ at $2 \mathrm{~m} \cdot \mathrm{s}-1$, which is between $51.27 \%$ and $94.87 \%$ lower than that produced by the cellulose pads.

There were significant differences in cooling efficiency among three thicknesses $(300,200,100 \mathrm{~m})$ of cooling pads. The evaporative cooling with $300 \mathrm{~mm}$ thickness of pads gave the highest cooling efficiency and the highest stem length and diameter, number and width of leaves, fruit length and diameter, weight of fresh fruit, as well as yield per plant, Elmsaad et al. 2017, Soponpongpipat et al. 2011.

\section{2- MATERIALS AND METHODS}

2-1- Ventilation system design: Two units of multi-stage evaporative cooling system was locally designed and fabricated for executing the ventilation process, Fig. (1). Each unit consists of three main parts. The first is air delivery part containing centrifugal fan and electric motor with technical specifications of $220 \mathrm{~V}, 50 \mathrm{~Hz}, 250 \mathrm{~W}$ and $20 \mathrm{cmm}$ for voltage, frequency, power and air charge respectively. The second part is primary cooling containing water thermal exchanger for cooling the natural air from $T_{1}$ to $T_{2}$ through the sensible cooling process. The third part is direct evaporative cooling for cooling the primary air from $T_{2}$ to $T_{3}$ through the adiabatic cooling process. This part consist of closed loop for air humidification which contains water source, pump, cellulose cooling pad and water collection device. The two units were installed in two down orifices with dimensions of $40 \mathrm{x} 40 \mathrm{~cm}$ through the front view of sprouting chamber, Fig. (2a). Four exhaust centrifugal fans and electric motors with technical specifications of " $220 \mathrm{~V}, 50 \mathrm{~Hz}, 100 \mathrm{~W}$ and $(5-10) \mathrm{cmm}$ for 
voltage, frequency, power and air charge respectively" were installed in four orifices in the back view of sprouting chamber, Fig. (2b).

2-2- Automatic control system design: Automatic control system was designed and installed for controlling on the ventilation process inside the sprouting and growth chamber, Fig. (3). Arduino Uno board was used for operating the ventilation system through receiving data from sensors and delivering signals to relays contactors.
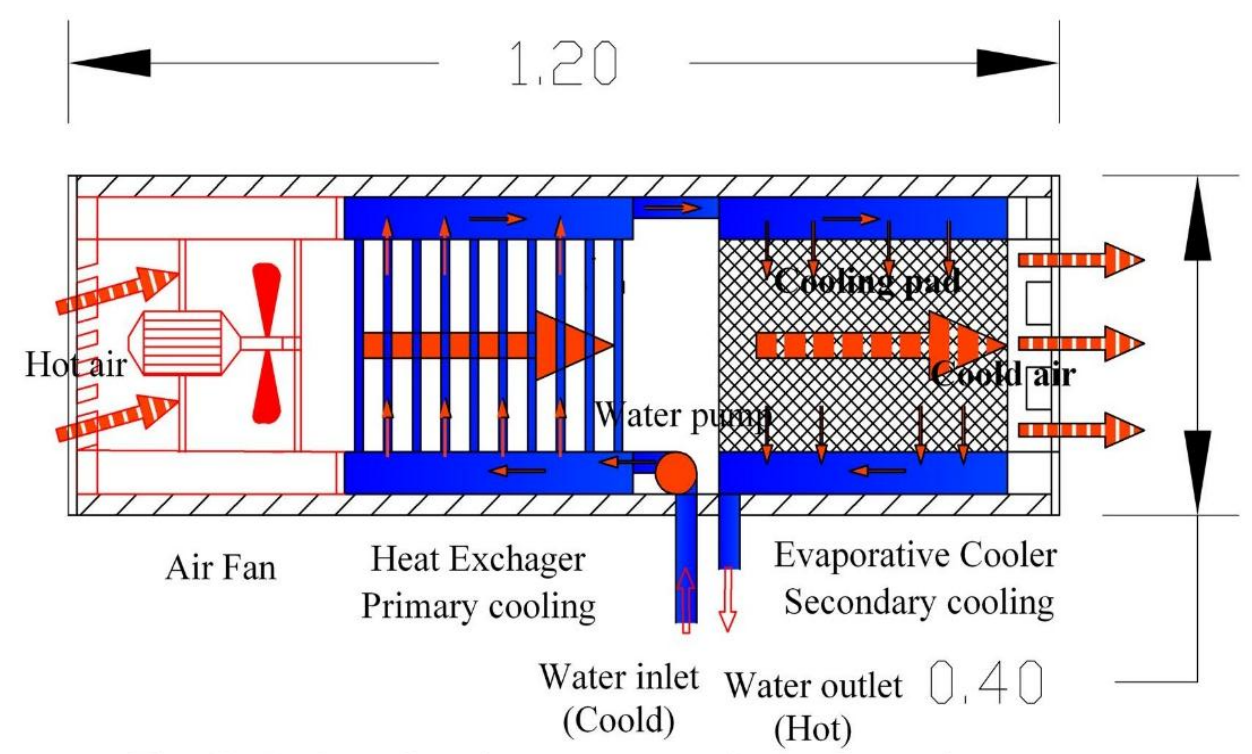

Fig. (1): Design of muti-stage evaporative cooling unit.

(Dimensions in $\mathrm{m}$ )

Humidity and temperature sensors collect and deliver data dealing with dry air temperature and relative humidity from the chamber environment to the AU board. After analyzing these dada, specific signals are delivered from the board to the multi-stage evaporative cooling units and the exhaust fans. Liquid-crystal display (LCD) is connect to the system to display the internal dry temperature and relative humidity. Arduino language is used to develop the needed program for managing the ventilation process inside the chamber. Personal Computer (PC) is used to write and deliver the operating program to the board through Universal Serial Bus (USB) cable. 


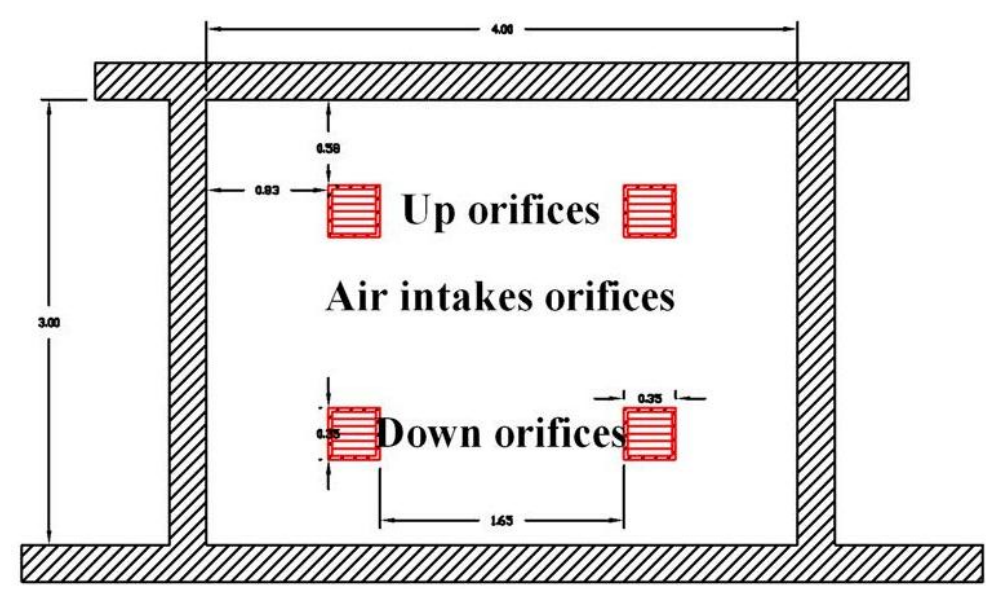

Fig. (2a):Front view.

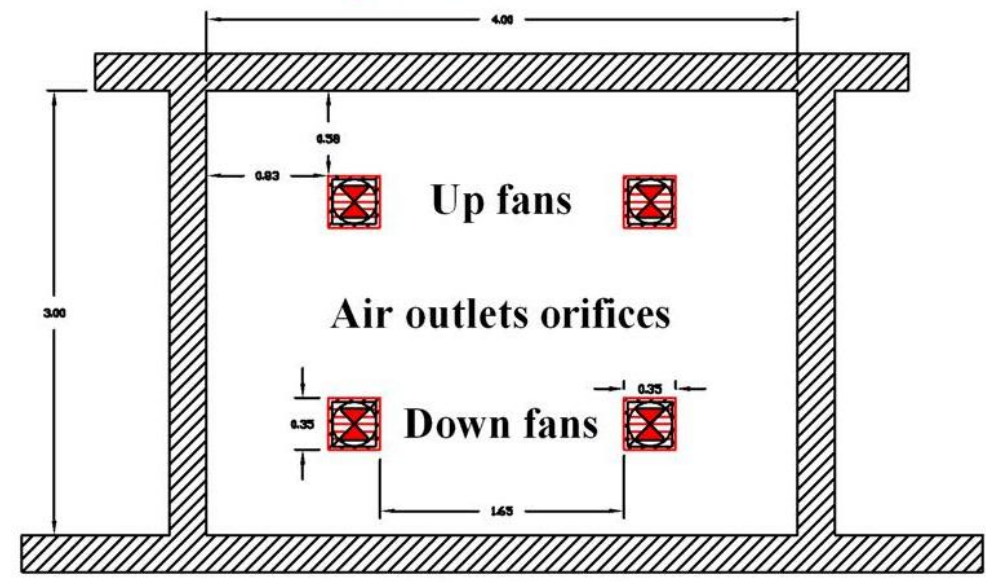

Fig. (2b): Back view.

Fig. (2): Ventilation orifices locations.

2-3- Air movement: According to design of the chamber and ventilation system air movement through the ventilation process is linear from the inlet orifices to the outlet orifices, Figs. 4, 5 and 6. Through the traditional case "using air conditioner" air moves from outside to the chamber through the inlet orifices by effect of low pressure in the chamber produced by the exhaust fans. Through the proposed case "using multistage evaporative cooling" air moves from outside to the chamber through the inlet orifices by evaporative cooling fans. Through the two cases, air moves from the chamber to outside by the exhaust fans. According to Fig. (4), ventilation efficiency in the chamber's corners area is expect to be less than its value in other area. 


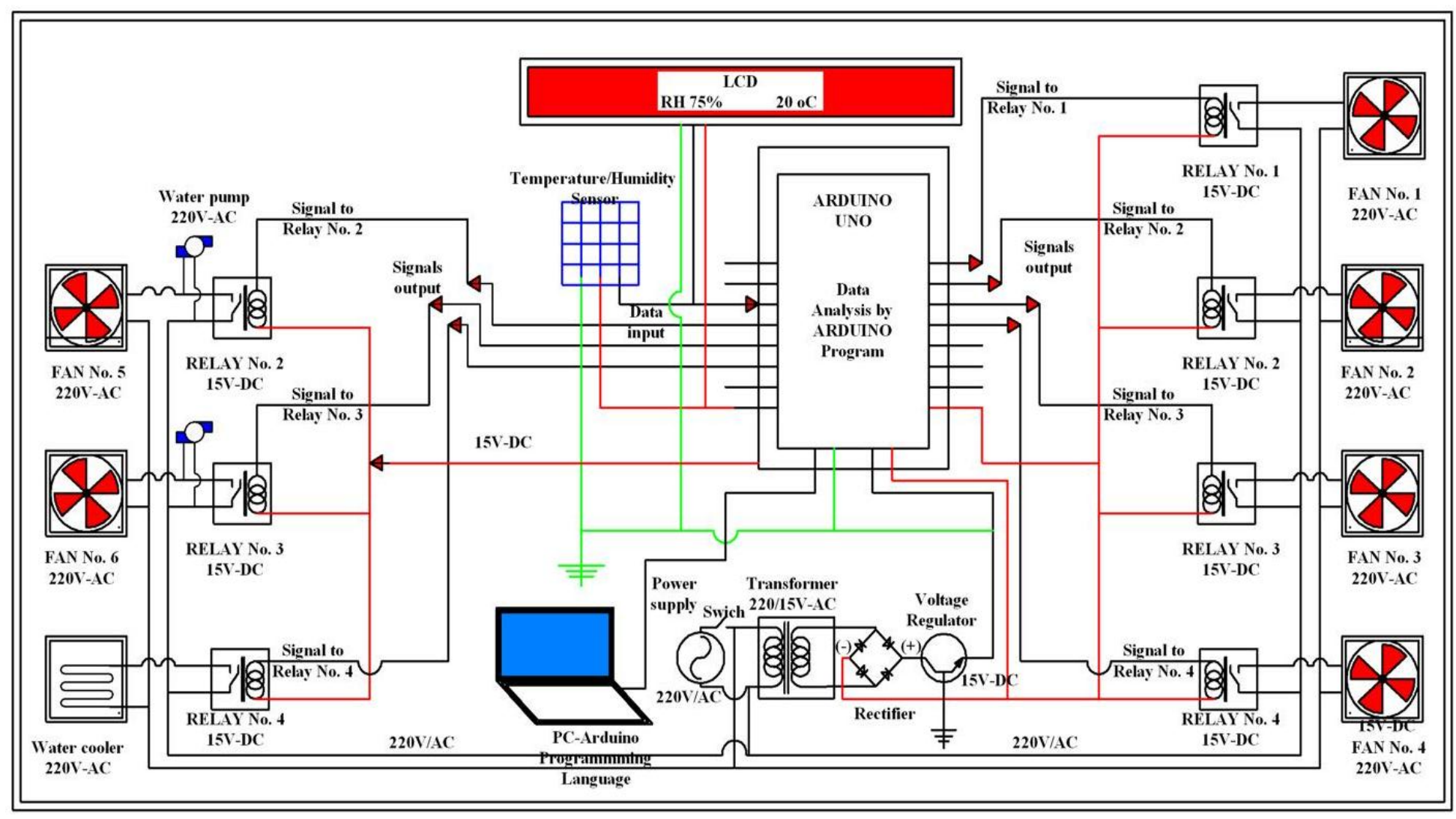

Fig. (3): Smart ventilation system controller. 
Also, the chamber's corners area could be changed according to location and number of the inlets and outlets orifices on the front and the back views. Therefore, great part of the ventilation trials concentrates on studying orifices location and its effect on production quality.

2-4- Ventilation trial: Three designs of ventilation systems and three levels of relative humidity were studied in factorial experiment in complete randomized bolt design, Table (1). The first design deals with using two units of multi-evaporative cooling with one exit for air exhaust. The second deals with using two units of multi-evaporative cooling with two exits for air exhaust. The third deals with using two units of multievaporative cooling with four exits for air exhaust. Similar systems with replacement of the multi-evaporative cooling units by air conditioner units were used as control. U shape tubes were used to collect two entrances or outlets in one orifice. Practically, 65, 75 and $85 \%$ of relative humidity (RH\%) were applied through the trial. Statistically, nine treatments of multi-stage evaporative cooling systems were compared with nine treatments of air conditioning systems, Table (1). Chamber temperature was fixed at $20^{\circ} \mathrm{C}$ for the twelve treatment, Hegab 2017. Cooper nutrients solution with concentration of 2PPP was used through the trial. Light intensity were fixed inside the chamber at $\left(36001 \mathrm{~m} / \mathrm{m}^{2}\right)$ through 12/h.day, Hegab 2018. Dry temperature ${ }^{\circ} \mathrm{C}$ and relative humidity $\%$ were measured inside and outside the chamber for measuring the system efficiency. Infected tray by Fungi, dry matter DM, crude protein $\mathrm{C}_{\mathrm{p}}$, crude fibers $\mathrm{C}_{\mathrm{f}}$, ash, ether extract $\mathrm{EE}$, and nitrogen free ether NFE percentages were measured and statistically analyzed at $(\mathrm{p}<0.05)$ for measuring the production quality.

\section{Table (1): Ventilation trial statistical design:}

\begin{tabular}{|c|c|c|c|c|c|c|c|}
\hline & \multicolumn{6}{|c|}{ Ventilation systems design } \\
\hline & & \multirow{2}{*}{\multicolumn{2}{|c|}{$\begin{array}{l}\text { Design (I) } \\
\text { One exit }\end{array}$}} & \multirow{2}{*}{\multicolumn{2}{|c|}{$\begin{array}{l}\text { Design (II) } \\
\text { Two exits }\end{array}$}} & \multicolumn{2}{|c|}{ Design (III) } \\
\hline & & & & & & FouI & xits \\
\hline & & $\begin{array}{c}\mathrm{AC} \\
\text { (control) }\end{array}$ & MSEC & $\begin{array}{c}\mathrm{AC} \\
\text { (control) }\end{array}$ & MSEC & $\begin{array}{c}\mathrm{AC} \\
\text { (control) }\end{array}$ & MSEC \\
\hline \multirow{3}{*}{$\begin{array}{l}\text { RH } \\
(\%)\end{array}$} & $65 \%$ & $\mathrm{C}_{1}$ & $\mathbf{T}_{1}$ & $\mathrm{C}_{2}$ & $\mathbf{T}_{2}$ & $\mathbf{C}_{3}$ & $\mathbf{T}_{3}$ \\
\hline & $75 \%$ & $\mathrm{C}_{4}$ & $\mathbf{T}_{4}$ & $\mathrm{C}_{5}$ & $\mathbf{T}_{5}$ & $\mathrm{C}_{6}$ & $T_{6}$ \\
\hline & $85 \%$ & $\mathbf{C}_{7}$ & $\mathbf{T}_{7}$ & $\mathrm{C}_{8}$ & $\mathbf{T}_{8}$ & $\mathrm{C}_{9}$ & T9 \\
\hline
\end{tabular}

Where: $\mathrm{Rh}$ is relative humidity (\%), $\mathrm{AC}$ is air conditioner and MSEC is multi-stage evaporative cooling. 


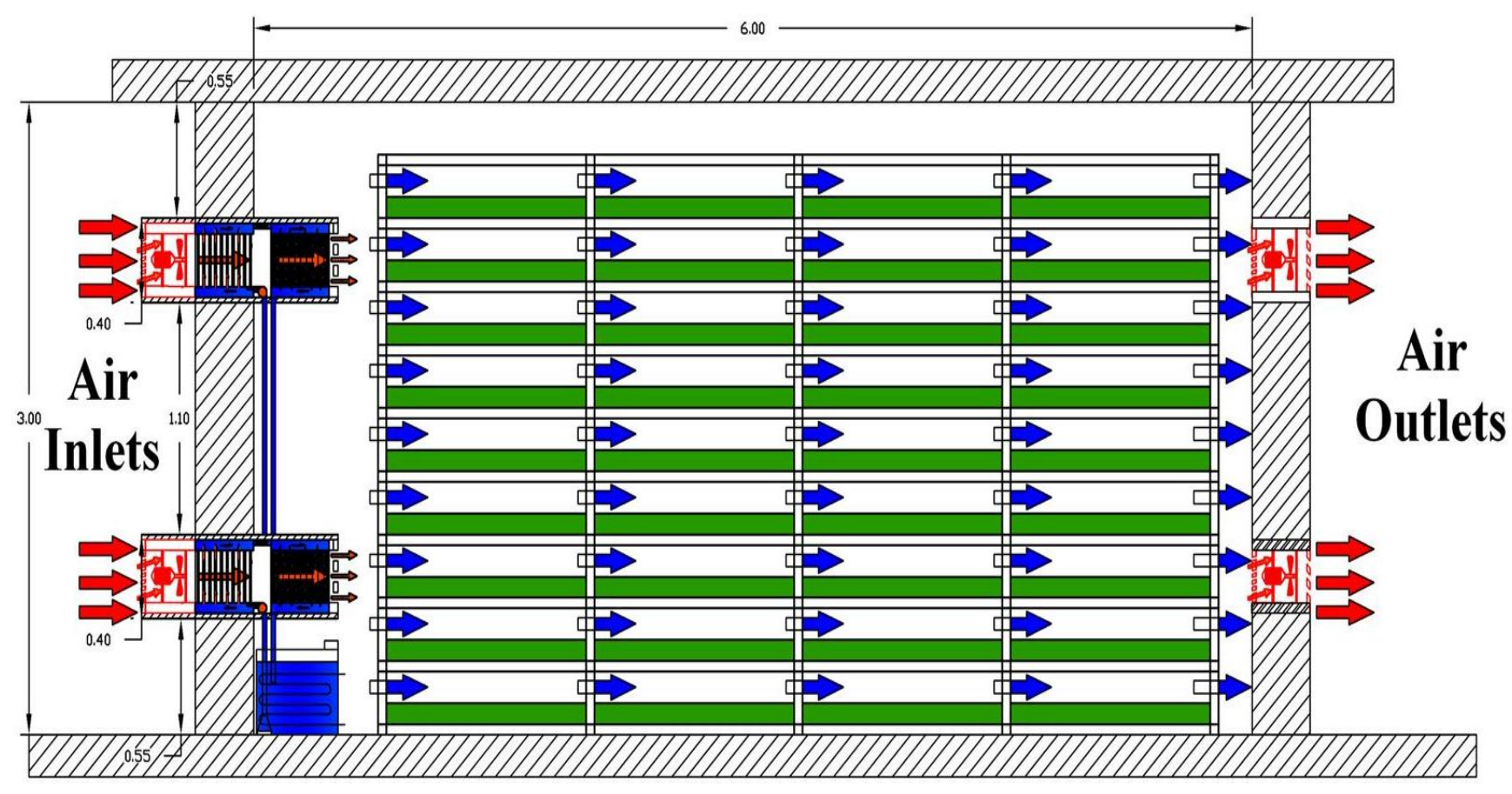

Fig. (4): Air ventilation using multi-stage evaporative cooling units. 


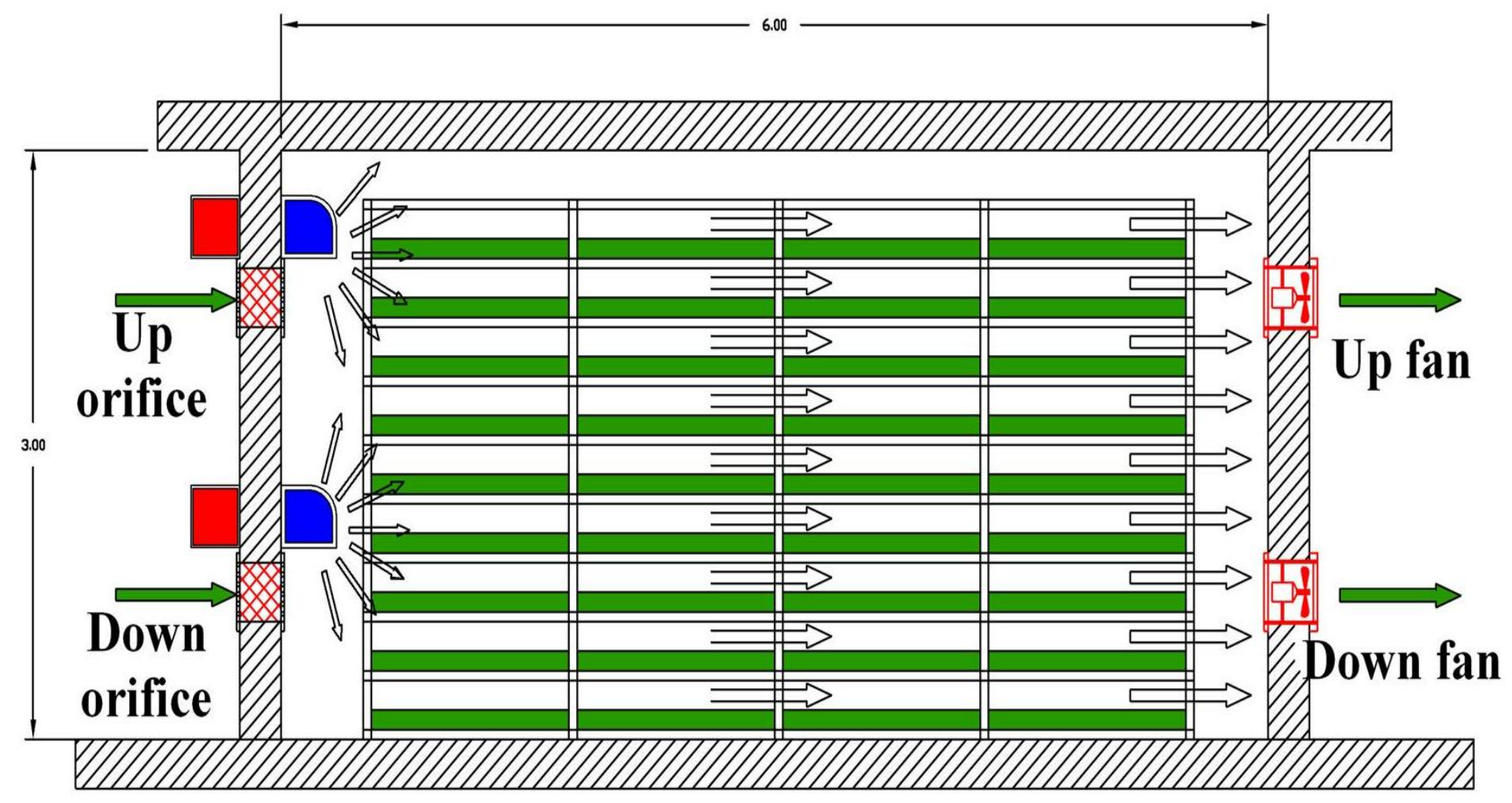

Fig. (5): Air movement using air conditioning units. 


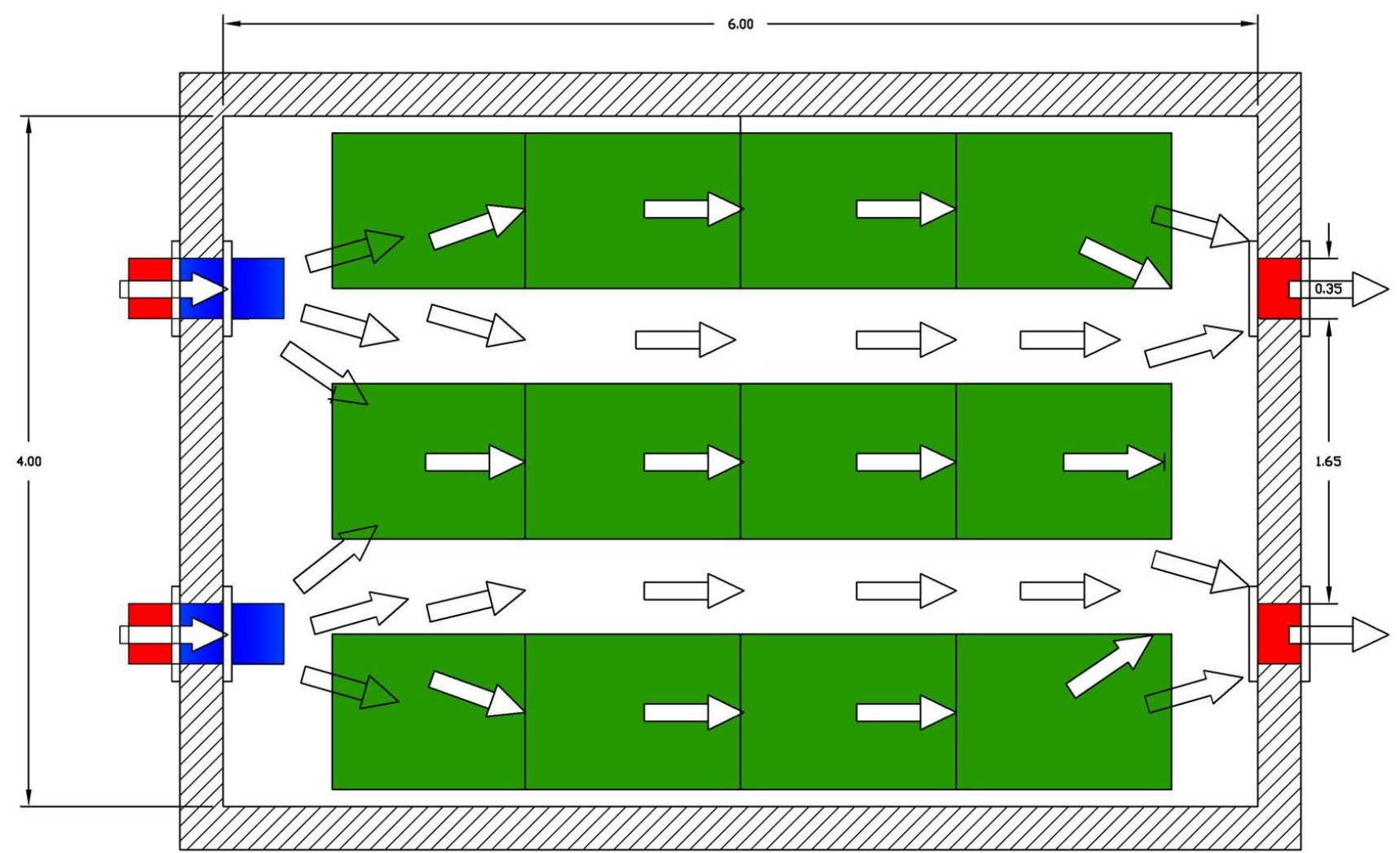

Fig. (6): Air movement through the horizontal level. 


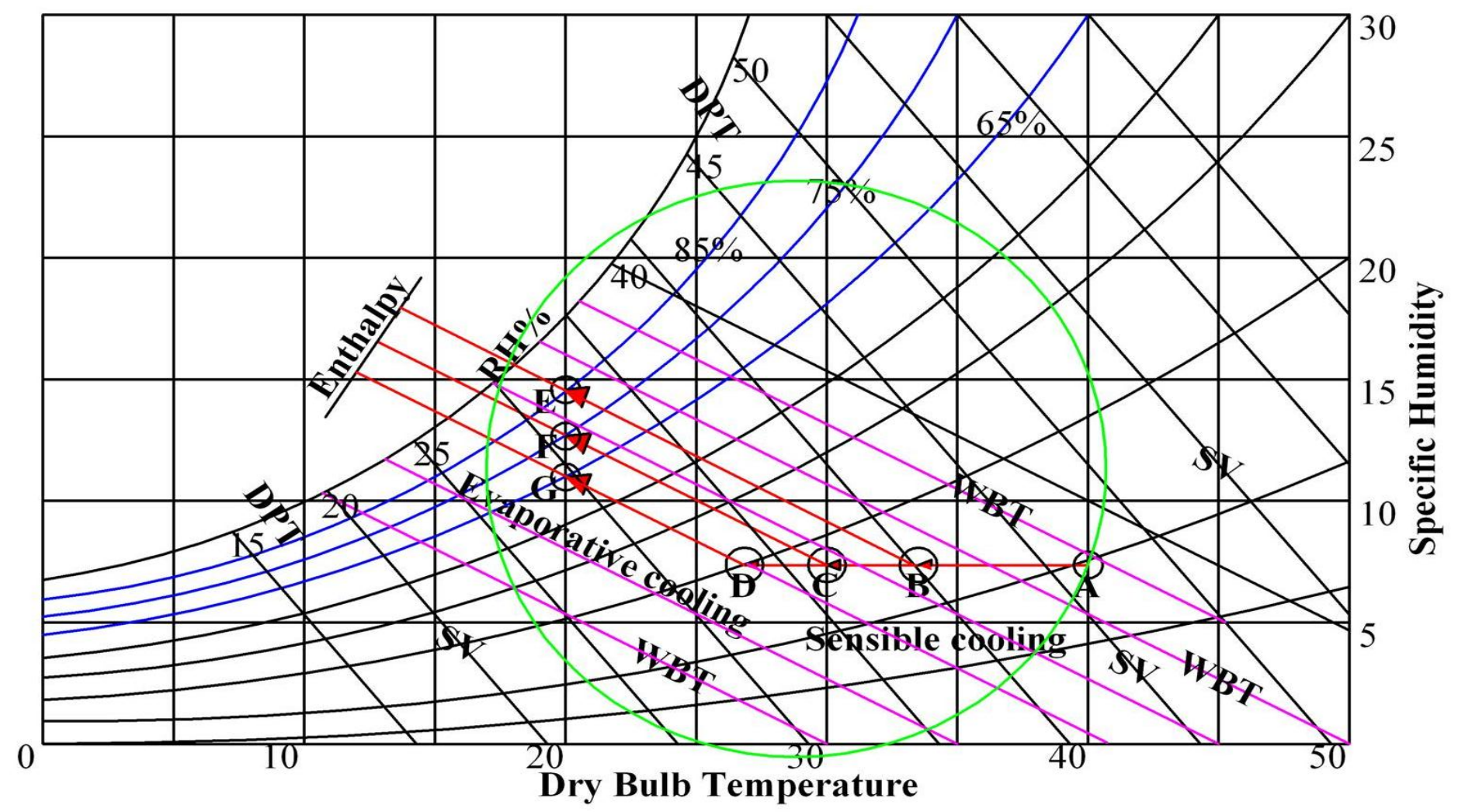

Fig. (7): Description of the multi-stage evaporative cooling processes on P. Chart. 
A randomized complete block design with two factors (RH\% levels and MSECS design) were used for analysis all data with six replications for each parameter. The treatment means were compared by least significant difference (L.S.D.) test as given by Snedecor and Cochran 1994 by used assistant program.

2-5- Ventilation process: Psychometric charts were used to describe the ventilation process of multi-evaporative cooling and air coediting systems. Through the multi-evaporative cooling system ventilation process is divided into two parts. The first is the sensible cooling process through indirect cooling process by using water thermal radiator. This process is determined by the horizontal line from the point $\mathrm{A}$ to the points B, C, and D, Fig.(7). The second is the adiabatic cooling process through increasing relative humidity by using multi-evaporative cooling. This process is determined by the declined lines from the points $\mathrm{B}, \mathrm{C}$, and $\mathrm{D}$, to the points $\mathrm{E}, \mathrm{F}$ and $\mathrm{G}$. Through the air conditioning system the process is divided into three parts. The first is sensible cooling process from the point $\mathrm{A}$ to point $\mathrm{B}$. The second is latent cooling process from the point $\mathrm{B}$ to point $\mathrm{C}$. The third is sensible cooling process from the point $\mathrm{C}$ to point $\mathrm{D}$.

\section{3-RESULTS AND DISCUSIONS}

\section{3-1- Temperature distribution under different ventilation systems:}

3-1-1-Vetilation system with one exit: Fig. (8a) shows dry bulb temperature $\left({ }^{0} \mathrm{C}\right)$ contouring map under air conditioner (control) with one exit for ventilation. This figure covers cross section area " $3 \mathrm{~m}$ high and $4 \mathrm{~m}$ wide" of the sprouting chamber. Due to the lighting units "heat source" were located on ceiling and the two sides of the chambers, therefore the heights contouring lines are concentrated at this location. Because of absence of the heat source and increasing humidity on the ground, a lower strip "within $50 \mathrm{~cm}$ of the ground" contains lower contouring lines. Since, there is one exit for air ventilation located in the back wall center. The remarked distances among contouring lines in the chamber core area are bigger than that are remarked close to the ceiling and the side walls. Logically, one exit is not enough to substitute the hot air close to the side walls and ceiling with a cold air. Therefore, the air temperature strip close to close to the side walls and ceiling is high in comparing with the core area. 
Fig. (8b) shows the temperature contouring map under evaporative cooling (case 1) with one exit for ventilation. Approximately, the whole remarks on this figure are similar to mentioned above on Fig. (8a). Table (2) summarizes statistical analysis results deal with the dry bulb temperature contouring data $\left({ }^{0} \mathrm{C}\right)$. The calculated temperature means for the air conditioner (control) and evaporative cooling (case 1) are 23.05 and $23.21{ }^{\circ} \mathrm{C}$, respectively. Statistically, there is no significant difference between the two means at $\mathrm{P}<0.05$. The values of the standard error are very small which are 0.21 and 0.25 for the air conditioner and the evaporative cooling under one exit respectively. This is considered a great result which agree with the research assumption toward replacing of the air conditioner with evaporative cooling system for air ventilation of the sprouting champers. This result agreed with Sapounas et al. 2008, Amer et al. 2014, Helmy et al. 2013, Ali and Hüseyin 2015, Mohammad et al. 2014, Oz et al. 2009, Perone et al. 2017, Mashonjowa et al. 2010, Villagrán et al. 2012, Ganguly and Ghosh 2011, and Yasutake et al. 2017 in using the evaporative cooling system in ventilation of vegetables, cot flowers, and seedling greenhouse production.

3-1-2-Vetilation system with two and four exits: Fig. (8c) shows dry bulb temperature $\left({ }^{0} \mathrm{C}\right)$ contouring map under evaporative cooling (case 2) with two exits for ventilation. Because of the two exits were located in the lower half of the back wall, a great change in lower half of the contouring map is remarked. Reversibly, there is no any remarked change in the upper part of the map. Statistically, the calculated values of temperature means are $23.05^{\mathrm{a}}$ and $22.74^{\mathrm{a} 0} \mathrm{C}$ for the control and evaporative cooling (case 2) respectively. Briefly, in comparing with the air conditioner map (control) the remarked change in the (case 2) is insignificant. This result is considered good but is not enough to confirm on locations of the ventilation exits has a great impact on ventilation process.

Fig. (8d) shows dry bulb temperature $\left({ }^{0} \mathrm{C}\right)$ contouring map under evaporative cooling (case 3) with four exits for ventilation. Because of the four exits were regular located within the back wall, a great change in both the upper and lower parts of the contouring map is remarked. Statistically, the calculated values of temperature means are $23.05^{\mathrm{a}}$ and $21.14^{\mathrm{b} 0} \mathrm{C}$ for the control and evaporative cooling (case 3), respectively. 
Briefly, in comparing with the air conditioner map (control) the remarked change in the (case 3) is significant. This result is considered great and confirmed on locations of the ventilation exits has a great impact on ventilation process. This result agreed with Hui and Cheung 2009, Franco et al. 2014, Chen et al.2014 Mehra et al. 2016, Elmsaad et al. 2017, Rafique et al. 2018, Noroozi and Veneris 2018, Han et al. 2018 in evaporative cooling of vegetables, cot flowers, and seedling production.

Table (2): Temperature contouring map data statistical analysis.

\begin{tabular}{|c|c|c|c|c|}
\hline & AC/1exit & EC/1 exit & EC/2 exits & EC/4 exits \\
\hline Mean & $23.05^{\mathrm{a}}$ & $23.21^{\mathrm{a}}$ & $22.74^{\mathrm{a}}$ & $21.14^{\mathrm{b}}$ \\
\hline Variance & 2.89 & 3.79 & 4.11 & 0.61 \\
\hline SD & 1.70 & 1.94 & 2.03 & 0.78 \\
\hline SE $\mathbf{\pm 0 . 0 5}$ & 0.21 & 0.25 & 0.25 & 0.10 \\
\hline
\end{tabular}

The symbols ( $\mathrm{a}$ and $\mathrm{b}$ ) are homogenous groups of DBT "00" which are significantly different.

Table (3) shows the effects of relative humidity and ventilation systems design on dry matter percentage (Dm\%) through the sprouting and growth trial. Statistically, using multi-stage evaporative cooling gives significant increase at $\mathrm{p}<0.05$ in dry matter \% comparing with using air conditioner "control". Exactly, fixing multi-stage evaporative cooling (MSECS) on $\mathrm{RH} 75 \%$ at dry bulb temperature (DBT) " $20^{\circ} \mathrm{C}$ " and using four ventilation exits gives greatest value of Dm\%. This result is referred to suitability of MSECS to refresh the chamber's air which minimizing production infection with Fungi in addition to controlling DBT and RH\%. This result agreed with Mashonjowa et al. 2010 Yasutake et al. 2017 and Perone et al. 2017.

Table (4) shows the effects of relative humidity and ventilation systems design on crude protein percentage $(\mathrm{Cp} \%)$ through the sprouting and growth trial. Using multi-stage evaporative cooling gives significant increase at $\mathrm{p}<0.05$ in $\mathrm{Cp} \%$ comparing with using air conditioner "control". Exactly, fixing multi-stage evaporative cooling (MSECS) on $\mathrm{RH} 75 \%$ at dry bulb temperature (DBT) " $20^{\circ} \mathrm{C}$ " and using four ventilation exits gives greatest value of $\mathrm{Cp} \%$. This result is referred to the same reasons mentioned above. 


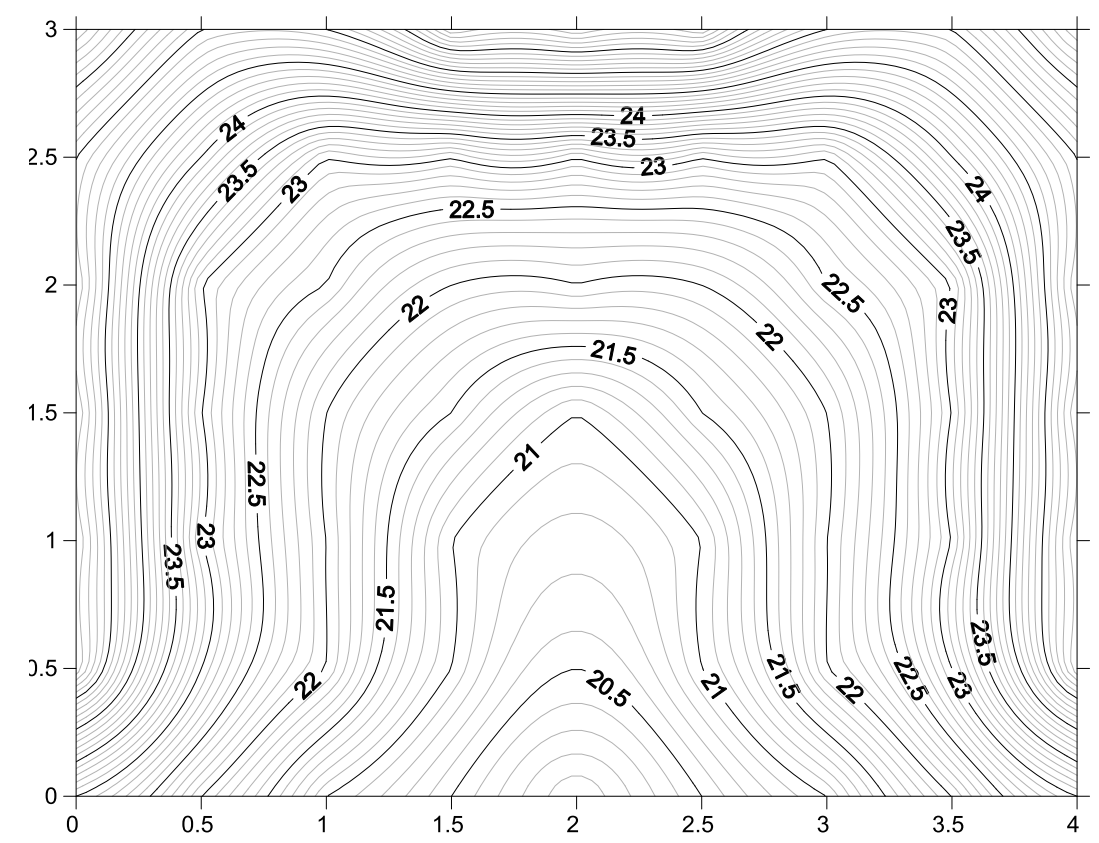

Fig. (8a): Temperature contouring map under AC/one exit.

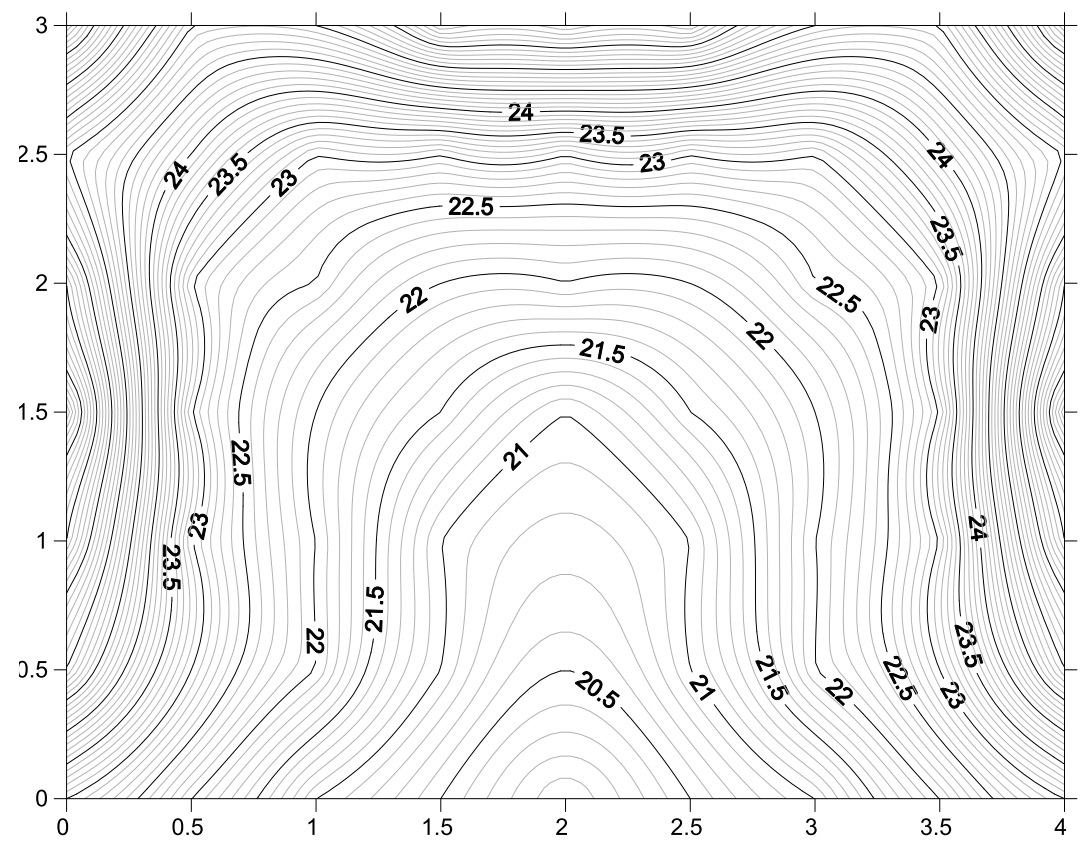

Fig. (8b): Temperature contouring map under EC/one exit. 


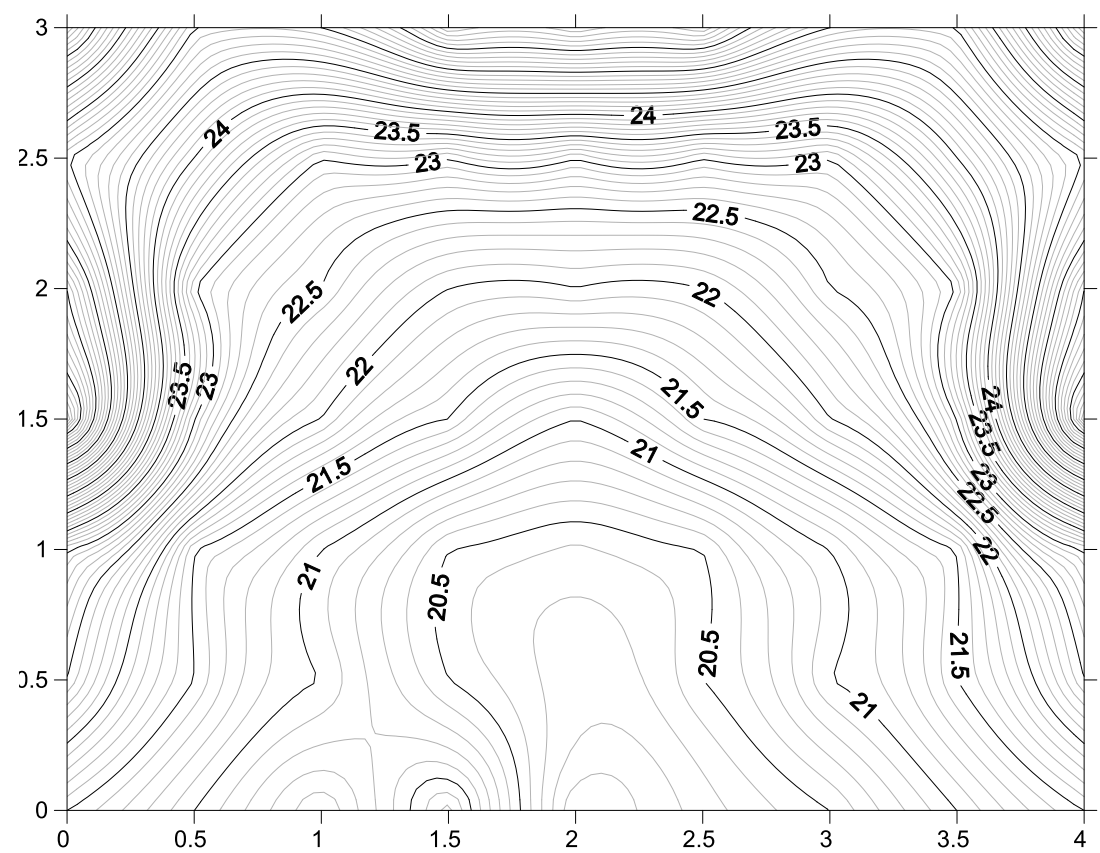

Fig. (8c): Temperature contouring map under EC/two exits.

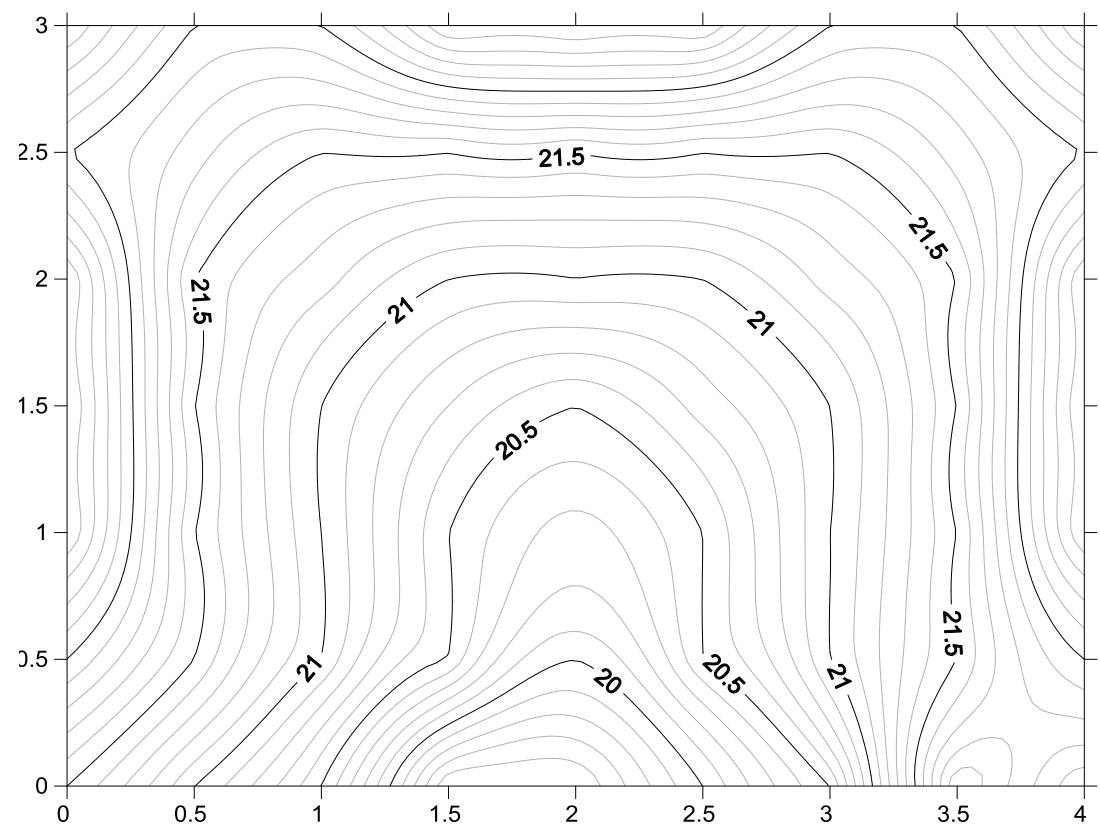

Fig. (8d): Temperature contouring map under EC/four exits 
Table (3): Effects of relative humidity and ventilation systems design on dry matter\% (sprouting trials statistical analysis results):

\begin{tabular}{|c|c|c|c|c|c|c|c|}
\hline & \multicolumn{6}{|c|}{ Ventilation systems design } \\
\hline & & \multicolumn{2}{|c|}{ Design (I) } & \multicolumn{2}{|c|}{ Design (II) } & \multicolumn{2}{|c|}{ Design (III) } \\
\hline & & \multicolumn{2}{|c|}{ One exit } & \multicolumn{2}{|c|}{ Two exits } & \multicolumn{2}{|c|}{ Four exits } \\
\hline & & $\begin{array}{c}\mathrm{AC} \\
\text { (control) }\end{array}$ & MSEC & $\begin{array}{c}\mathrm{AC} \\
\text { (control) }\end{array}$ & MSEC & $\begin{array}{c}\mathrm{AC} \\
\text { (control) }\end{array}$ & MSEC \\
\hline \multirow{3}{*}{$\begin{array}{l}\text { RH } \\
(\%)\end{array}$} & $65 \%$ & $13.033^{\mathrm{k}}$ & $13.500^{\mathrm{hij}}$ & $13.750^{\mathrm{ghi}}$ & $13.867^{\text {fgh }}$ & $13.883^{\text {fgh }}$ & $14.083^{\mathrm{efg}}$ \\
\hline & $75 \%$ & $14.250^{\mathrm{def}}$ & $14.367^{\mathrm{de}}$ & $14.533^{\mathrm{cd}}$ & $14.917^{\mathrm{c}}$ & $\underline{15.517^{\mathrm{b}}}$ & $\underline{15.950^{\mathrm{a}}}$ \\
\hline & $85 \%$ & $13.117^{\mathrm{jk}}$ & $13.433^{\mathrm{ijk}}$ & $13.750^{\text {ghi }}$ & $14.033^{\mathrm{efg}}$ & $13.967^{\mathrm{efg}}$ & $14.067^{\mathrm{efg}}$ \\
\hline
\end{tabular}

Where: $\mathrm{Rh}$ is relative humidity (\%), $\mathrm{AC}$ is air conditioner and MSEC is multi-stage evaporative cooling. Alpha 0.05, Standard Error for comparison 0.2047, Critical T Value 1.988, Critical Value for Comparison 0.4070. The (a, b, c, d, $\mathrm{e}, \mathrm{f}, \mathrm{g}, \mathrm{h}, \mathrm{i}, \mathrm{j}$ and $\mathrm{k}$ ) are homogenous groups of Dm \% which are significantly different from one group to another. 
Table (4): Effects of relative humidity and ventilation systems design on crude protein\% (sprouting trials statistical analysis results):

\begin{tabular}{|c|c|c|c|c|c|c|c|}
\hline & \multicolumn{6}{|c|}{ Ventilation systems design } \\
\hline & & \multicolumn{2}{|c|}{ Design (I) } & \multicolumn{2}{|c|}{ Design (II) } & \multicolumn{2}{|c|}{ Design (III) } \\
\hline & & \multicolumn{2}{|c|}{ One exit } & \multicolumn{2}{|c|}{ Two exits } & \multicolumn{2}{|c|}{ Four exits } \\
\hline & & $\begin{array}{c}\mathrm{AC} \\
\text { (control) }\end{array}$ & MSEC & $\begin{array}{c}\mathrm{AC} \\
\text { (control) }\end{array}$ & MSEC & $\begin{array}{c}\mathrm{AC} \\
\text { (control) }\end{array}$ & MSEC \\
\hline \multirow{3}{*}{$\begin{array}{l}\text { RH } \\
(\%)\end{array}$} & $65 \%$ & $12.150^{\mathrm{i}}$ & $12.367^{\mathrm{ij}}$ & $12.450^{\mathrm{ij}}$ & $12.717^{\text {gh }}$ & $12.600^{\mathrm{hi}}$ & $12.917^{\mathrm{gh}}$ \\
\hline & $75 \%$ & $14.567^{\mathrm{e}}$ & $15.817^{\mathrm{d}}$ & $15.817^{\mathrm{c}}$ & $16.33 b^{c}$ & $\underline{16.500}^{\mathrm{ab}}$ & ${\underline{16.683^{a}}}^{\mathrm{a}}$ \\
\hline & $85 \%$ & $12.433^{\mathrm{ij}}$ & $12.633^{\mathrm{hi}}$ & $13.250^{\mathrm{fg}}$ & $13.467^{\mathrm{f}}$ & $13.450^{\mathrm{f}}$ & $13.617^{\mathrm{e}}$ \\
\hline
\end{tabular}

Where: $\mathrm{Rh}$ is relative humidity (\%), AC is air conditioner and MSEC is multi-stage evaporative cooling. Alpha 0.05, Standard Error for comparison 0.1902, Critical T Value 1.988, Critical Value for Comparison 0.3782. The (a, b, c, d, $e, f, g, h, i$ and $j$ ) are homogenous groups of $\mathrm{Cp} \%$ which are significantly different from one group to another. 
Table (5): Effects of relative humidity (75\%) and ventilation systems design (MSEC with four exits) on other technical specs (sprouting trials statistical analysis results).

\begin{tabular}{|c|c|c|c|c|c|c|c|c|}
\hline & $\operatorname{Ash} \downarrow$ & $\begin{array}{r}\text { Crude } \\
\text { fiber } \downarrow\end{array}$ & $\begin{array}{c}\text { Fresh } \\
\text { weight } \uparrow\end{array}$ & $\begin{array}{c}\text { Root } \\
\text { Layer } \\
\text { thickness } \downarrow\end{array}$ & $\begin{array}{c}\text { Vegetation } \\
\text { growth } \\
\text { high } \uparrow\end{array}$ & $\begin{array}{c}\text { Ether } \\
\text { Extract } \downarrow\end{array}$ & NFE $\downarrow$ & $\begin{array}{c}\text { Infection } \\
\text { Rate } \downarrow\end{array}$ \\
\hline MSEC & $3.150^{f}$ & $13.233^{\mathrm{e}}$ & $5.4833^{\mathrm{de}}$ & $1.4833^{\mathrm{g}}$ & $18.217^{\mathrm{e}}$ & $3.250^{f}$ & $48.634^{c}$ & $1.6833^{\mathrm{d}}$ \\
\hline $\begin{array}{c}\mathrm{AC} \\
\text { (control) }\end{array}$ & $3.450^{\mathrm{e}}$ & $13.637^{\mathrm{d}}$ & $5.0500^{\mathrm{f}}$ & $1.7833^{\mathrm{f}}$ & $17.983^{\mathrm{f}}$ & $3.500 \mathrm{~d}^{\mathrm{e}}$ & $50.351^{\mathrm{b}}$ & $2.4000^{c}$ \\
\hline SE干0.05 & 0.1431 & 0.1928 & 0.1198 & 0.1437 & 0.2293 & 0.1251 & 0.5752 & 0.3019 \\
\hline CVC & 0.2846 & 0.3833 & 0.2382 & 0.2858 & 0.4559 & 0.2488 & 0.8279 & 0.6003 \\
\hline
\end{tabular}

Where: AC is air conditioner and MSEC is multi-stage evaporative cooling. Alpha 0.05, Standard Error for comparison 0.1902, Critical T Value 1.988, CVC is Critical Value for Comparison. The (b, c, d, e, f and g) are homogenous groups which are significantly different from one group to another. 
Table (5) shows the effects of relative humidity and ventilation systems design on Crude fiber\%, Ash\%, Ether Extract\%, Nitrogen Free Ether\%, Fresh Weight $(\mathrm{kg})$, Root Layer Thickness $(\mathrm{cm})$, Vegetation Growth High (cm) and Infection Rate \%. The tabulated means of $\mathrm{C}_{\mathrm{f}} \%$, Ash\%, EE\%, NFE\%, RLT $(\mathrm{cm})$ and IR\% are lower than its values in the controls. Because of high values of these specs are not advisable in animals' rations. Therefore, the using multi-stage evaporative cooling (MSECS) on RH $75 \%$ at dry bulb temperature (DBT) " $20^{\circ} \mathrm{C}$ " and using four ventilation exits has a positive effect on these criteria. Fresh Weight $(\mathrm{kg})$ and Vegetation Growth High $(\mathrm{cm})$ are higher than its values in comparing with its controls.

Since, high values of these specs are advisable in animals' rations. Therefore, the using multi-stage evaporative cooling (MSECS) on RH $75 \%$ at dry bulb temperature (DBT) " $20^{\circ} \mathrm{C}$ " and using four ventilation exits has a positive effect on these criteria. This result is referred to the same reasons mentioned above. This result agreed with Soponpongpipat et al. 2011 and Elmsaad et al. 2017.

\section{SUMMARY AND CONCLUSION}

Summarizing the above mentioned results revealed to the following points:

1- Using smart MSECS at RH75\% with four exhaust fans led to significant decrease in the $\mathrm{T}_{\mathrm{db}}$ variance (from $23.05^{\mathrm{a}}$ to $21.14^{\mathrm{b}}{ }^{\circ} \mathrm{C}$ at $\mathrm{p}<0.05)$ comparing with the ACS (control).

2- Using smart MSECS at RH75\% with one or two exhaust fans hasn't significant effect on the $\mathrm{T}_{\mathrm{db}}$ variance (from $23.05^{\mathrm{a}}$ to $22.74^{\mathrm{a}}$ and $23.21^{\mathrm{a}}$ ${ }^{\circ} \mathrm{C}$ at $\left.\mathrm{p}<0.05\right)$ comparing with the ACS.

3- Using smart MSECS at RH75\% with four exhaust fans led to incrowd and uniformity of Tdb contouring lines (from line 20 to 22) comparing with the ACS (from line 20 to 27).

4- Using smart MSECS at RH75\% with four exhaust fans led to significant increase in the desired properties of the green fodder such as percentage of dry matter Dm and crude protein $\mathrm{Cp}$, and the in desired properties such as percentage of crude fiber $\mathrm{C}_{\mathrm{f}}$ and Ash at $(\mathrm{p}<0.05)$. 
Therefore, the research recommendation is substitution of the ACS by smart MSECS with four exhaust fans to manage the bioenvironmental conditions of the hydroponics systems at $\mathrm{T}_{\mathrm{bd}} 20^{\circ} \mathrm{C}$ and $\mathrm{RH} 75 \%$.

\section{REFERENCES}

Ali, M. and Hüseyin, H. 2015 Performance analysis of a greenhouse fanpad cooling system: gradients of horizontal temperature and relative humidity, J. of Agric. Sci. 21 (2015):132-143 www.agri.ankara.edu.tr/journal

Amer, O., Boukhanouf, R. and Ibrahim H. 2014 A review of evaporative cooling technologies, 2014 APCBEES Nottingham Conferences $\quad$ Proceeding: 119-125. DOI: 10.7763/IJESD.2015.V6.571

Barreto-Mendes, F. L., Yanagi Junior, T., Luiz-de Oliveira, J. and Osorio-Saraz, J.A. (2017) Assesment of evaporative cooling efficiency in greenhouses equiped with wetted porous plates DYNA, 84(203), pp. 118-125

Chen, J., Cai, Y., Xu, F., Hu, H. and Ai, Q. 2014 Analysis and optimization of the fan-pad evaporative cooling system for greenhouse based on CFD, Hindawi Publishing Corporation, Advances in Mechanical Engineering, Volume 2014, Article ID 712740, 8 pages, http://dx.doi.org/10.1155/2014/712740

Chijioke, O. V. 2017 Review on Evaporative Cooling Systems, Greener Journal of Science, Engineering and Technological Research, Vol. 7 (1), pp. 001-020

Elmsaad, E.; Abbas, O. and Ali, M. 2017 Impact of different thicknesses of evaporative cooling pads on crop yield in greenhouse, Intern. J. of Agric. Innovations and Research, Volume 5, Issue 5: 882-888

Franco, A., Valera D. L., and Peña, A. 2014 Energy efficiency in greenhouse evaporative cooling techniques: cooling boxes versus cellulose pads, Energies 7, 1427-1447; doi: 10.3390/en7031427 
Ganguly, A. and Ghosh, S. 2011 A review of ventilation and cooling technologies in agricultural greenhouse application, Iranica Journal of Energy \& Environment 2 (1): 32-46

Han, G., Feng, X. and Zhao, S. 2018 A multistage regulation method for the pad and fan cooling system, Agriculture, Forestry and Fisheries, 2018; 7(1): 1-5, http://www.sciencepublishinggroup.com/j/aff

Hegab. K. K. 2018a Automatic environmental-control in the biosystem for sprouting soilless hydroponics barley, MJAE, Volume ( ) Pp:

Hegab. K. K. 2018b Light uniformity improvement inside the sprouting environment and product evaluation, MJAE, Volume ( ) Pp:

Helmy, M. A., Eltawil1, M. A., Abo-shieshaa, R. R. and El-Zan, N. M. 2013 Enhancing the evaporative cooling performance of fan-pad systemusing alternative pad materials and water film over the greenhouse roof. Agric. Eng. Int.: CIGR Journal, Vol. 15, No.2:173-187

Hui, S. C. M. and Cheung, W. Y., 2009. Two-stage evaporative cooling systems in hot and humid climate, In Proceedings of the TianjinHong Kong Joint Symposium, 29-30 Jun 2009, Tianjin, China, pp. 64-76.

Mashonjowa, E. , Ronsse, F. , Milford, J. R. , Lemeur, R. , and Pieters, J. G. (2010) Measurement and simulation of the ventilation rates in a naturally ventilated Azrom-type greenhouse in Zimbabwe, Applied Engineering in Agriculture, 26(3), 475-488

Mehra, M. K.; Bansal, V., Jhala, R. S 2016 A review on multi-stage evaporative cooler, IJATES Vol. No. 4, Issue No. 11:166-177, www.ijates.com

Mohammad, A., Mat, S., Alrubaih, M. S. and Al-abidi, A. A. (2014) Optimization of cooling load for different greenhouse models in Malaysia, Int. J. of Renewable Energy Res. Vol. (2014):42-48

Noroozi, A. and Veneris, Y. S. 2018 Thermal assessment of a novel combine evaporative cooling wind catcher, Energies 2018, 11, 442; doi:10.3390/en11020442 www.mdpi.com/journal/energies 
Oz, H., Atilgan, A., Buyuktas, K. and Alagoz, T. (2009) The efficiency of fan-pad cooling system in greenhouse and building up of internal greenhouse temperature map, A. J. B., Vol. 8 (20):5436-5444

Perone, C., Fucci, F., La Fianza, G., Brunettia, L., Giametta, F., Catalano, P., Bianchi, B. (2017) Experimental study of a mechanical ventilation system in a greenhouse, Chemical Engineering Transactions, Vol. 58: 811-816

Rafique, M. M., Rehman, S. , Alhems, L. M. and Shakir, M. A. (2018) A Liquid desiccant enhanced two stage evaporative cooling system- development and performance evaluation of a test rig, Energies 2018, 11, 72; doi:10.3390/en11010072, www.mdpi.com/journal/energies

Sapounas, A.A., Nikita-Martzopoulou, Ch., Bartizans, T. and Kittas, C. (2008) Fan and Pad Evaporative Cooling System for Greenhouses: Evaluation of a Numerical and Analytical Model, Proc. IW on Greenh. Environ. Control \& Crop Prod. In Semi-Arid Regions: 131-138

Silva, F.; De A. S. E. and Azevedo, C. A. V. 2009 Principal components analysis in the software assistat-statistical attendance. In: World congress on computers in agriculture, 7, Reno-Nv-Usa: American society of agricultural and biological engineers.

Snedecor GW, Cochran WG, 1994. Statistical Methods. $9^{\text {th }}$ Ed., Iowa State Univ. Press, Ames, Iowa, USA.

Soponpongpipat, N., Jaruyanon, P., and Nanetoe, S. 2011 The thermoeconomics analysis of the optimum thickness of doublelayer insulation for air conditioning duct. Energy Research Journal, Vol.1: 146-151

Villagrán, E. A., Gil, R., Acuña J.F., and Bojacá, C. R. 2012 Optimization of ventilation and its effect on the microclimate of a Colombian multispan greenhouse, Agro. Colombiana 30(2), 282288

Worley, J. 2009 Greenhouses heating, cooling and ventilation, The University of Georgia, Cooperative and Extension, College of 
Agricultural and Environmental Sciences \& Family, and Consumer Sciences. Bulletin 792. https://athenaeum.libs.uga.edu/bitstream/handle

Yasutake, D., Tanioka, H., Ino, A., Takahashi, A., Yokoyama, T., Mori, M., Kitano, M., and Miyauchi, K. 2017 Dynamic evaluation of natural ventilation characteristics of a greenhouse with $\mathrm{CO}_{2}$ enrichment, Academia Journal of Agricultural Research 5(10): 312-319.

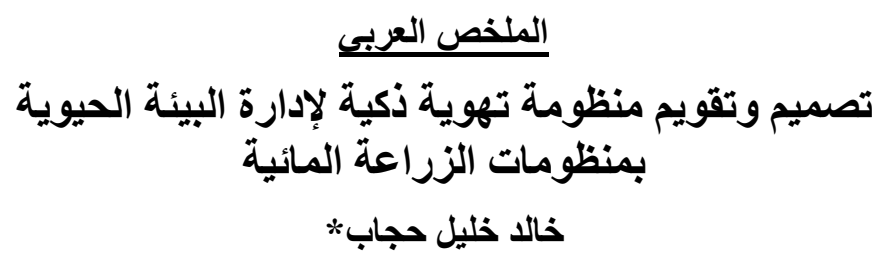

المشكلة: بالرغم من إنخفاض التكاليف الثابتة لإنشاء منظومات التبريد التبخيرى الى النصف

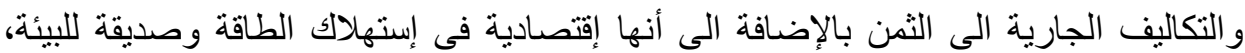

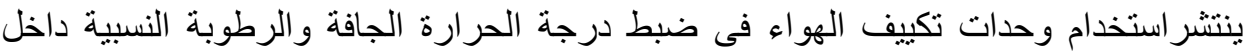

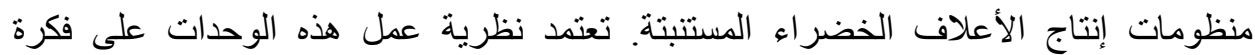

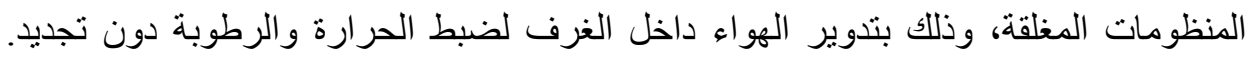

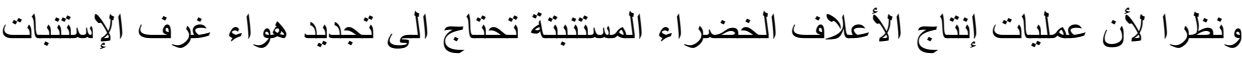

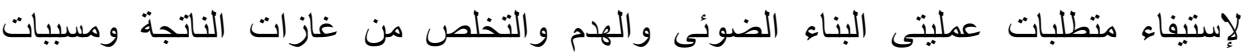

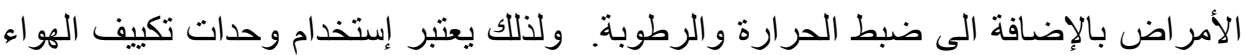
حلاً خطئاً للمشكلة.

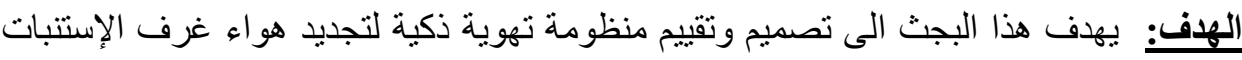

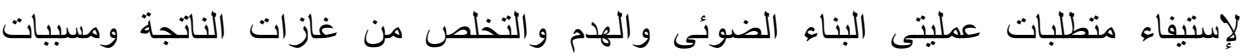

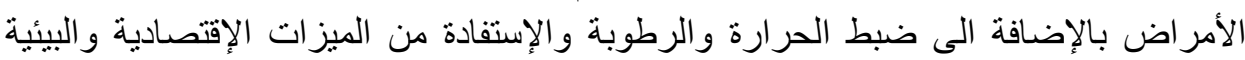

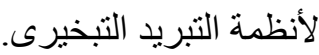

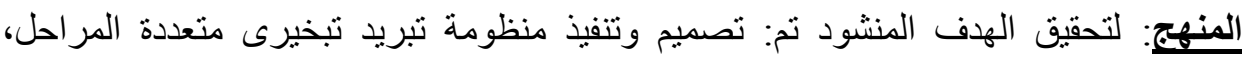

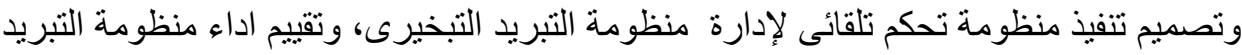

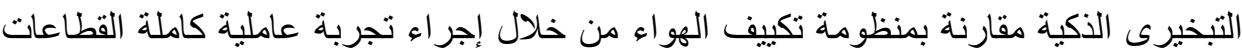

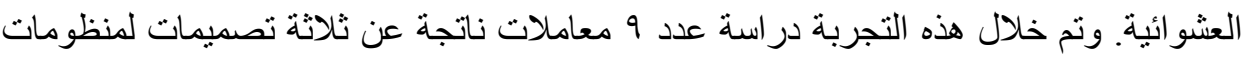

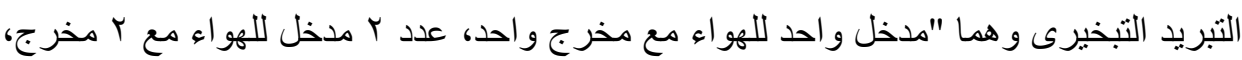

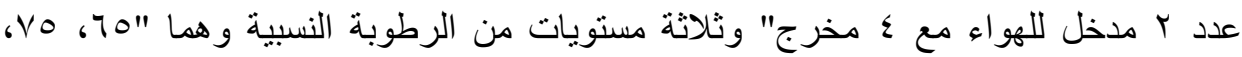

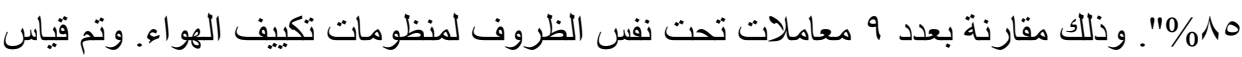
درحة الحر ارة الجافة و الرطوبة النسبية داخل وخارج الغرفة للتعرف على على كفاءة نظام التهوية.

*قمم الهندة الزراعية ـ كلية الزراعة - جامعة القاهرة 


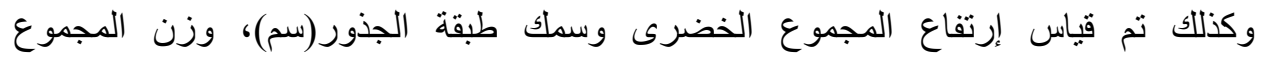

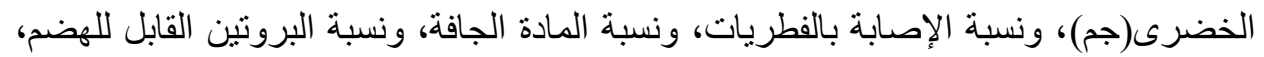

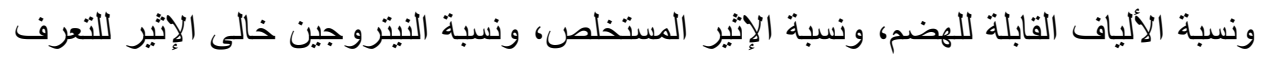
على جودة المنتج.

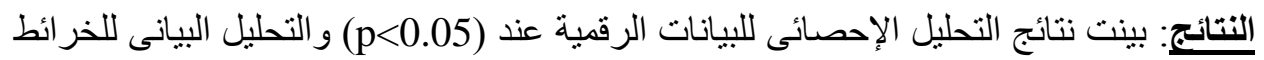

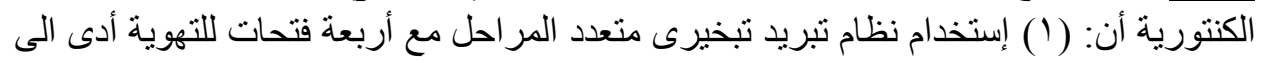

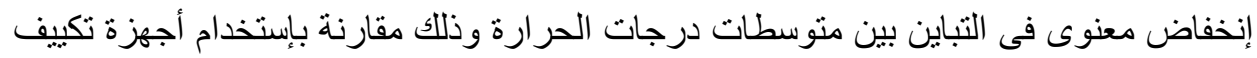

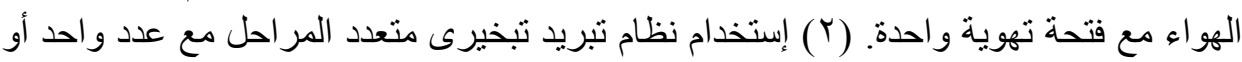

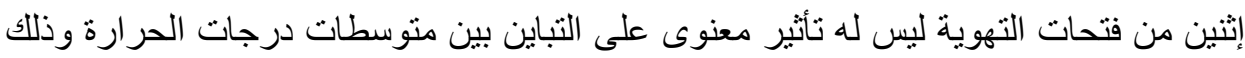

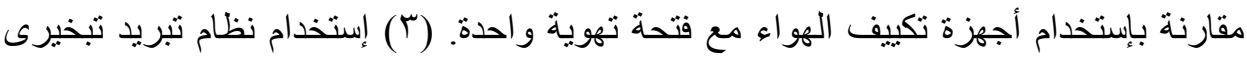

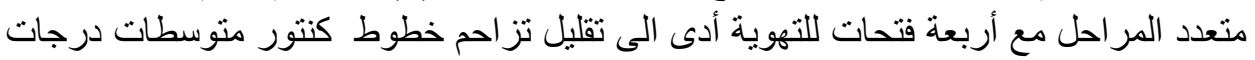

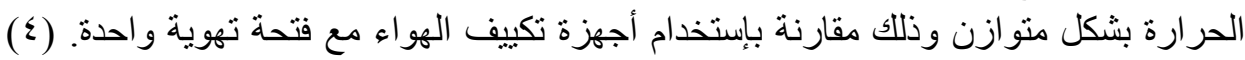

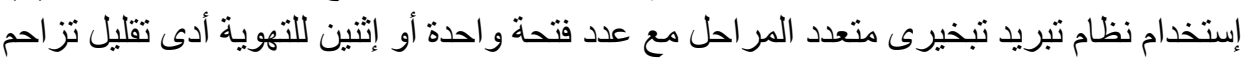

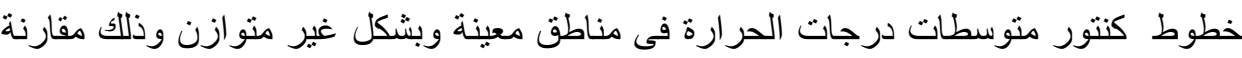

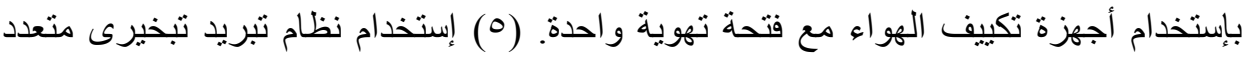

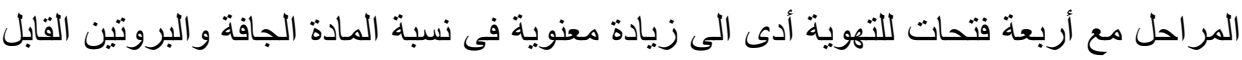

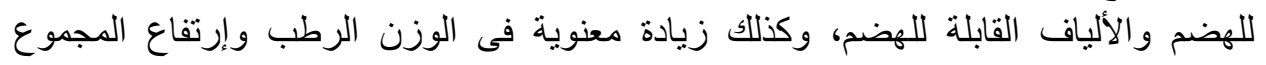

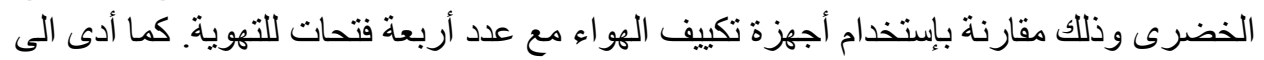

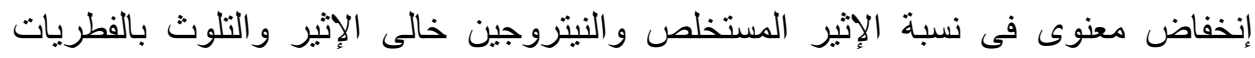
بإعتبار ها مكونات غير مرغون فية في الإثير علائق الحيوان.

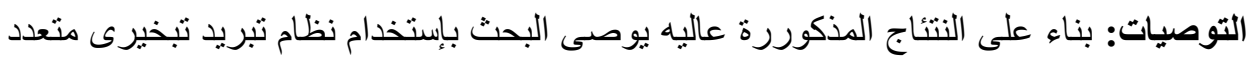

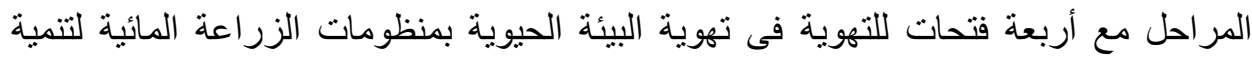

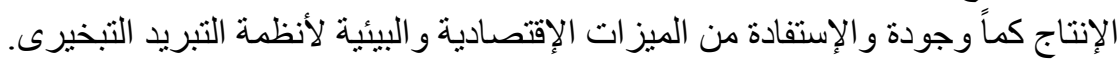

